\title{
EQUITY
}

Vol. 23, No.2, 2020, 151-166

DOI: 10.34209 /equ.v23i2.2084

P-ISSN 0216-8545 | E-ISSN 2684-9739

Diunggah : September 2020

Diterima : Desember 2020

Dipublikasi : Desember 2020

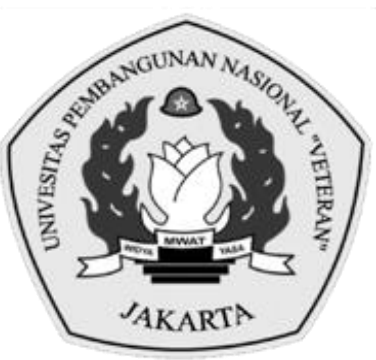

\section{EFEKTIFITAS SISTEM PENGENDALIAN INTERN DALAM MENCEGAH KECURANGAN DI PERUSAHAAN DAERAH}

\author{
Haidar Humam ${ }^{1 *}$, Lilis Ardini², Kurnia Kurnia ${ }^{3}$ \\ 1Haidar.stiesia@gmail.com, 2lilisardini@stiesia.ac.id, 3kurnia@stiesia.ac.id \\ 1, 2,35ekolah Tinggi Ilmu Ekonomi Indonesia, Indonesia \\ *Penulis Korespondensi
}

\begin{abstract}
Abstrak
Sistem pengendalian internal pada Perusahaan Daerah Air Minum (PDAM) Tirta Kahuripan Kabupaten Bogor dilaksanakan untuk mengetahui apakah sistem manajemen sudah dilaksanakan dengan baik atau tidak dan menghindari terjadinya kebocoran biaya. Sistem pengendalian intern yang dilakukan di PDAM Kabupaten Bogor dalam hal pemisahan tugas dan wewenang masih belum berjalan maksimal dengan bukti adanya rangkap jabatan. Hal tersebut dikhawatirkan akan adanya penyalahgunaan wewenang jabatan yang berakibat pada kecurangan. Sistem pengendalian intern sangat diharapkan bisa mencegah sebuah kecurangan yang akan terjadi. Hal yang ingin dicapai dalam penelitian ini adalah untuk menganalisis keefektifan penerapan sistem pengendalian intern sebagai upaya pengendalian ataupun bahkan pencegahan kejadian tindakan kecurangan. Metode kualitatif diterapkan dalam penelitian ini dengan menggunakan Teknik pengumpulan data yang dilakukan adalah melalui observasi (observation) dan wawancara (in depth interview). Hasil dari penelitian ini menunjukkan bahwa PDAM Tirta Kahuripan Kabupaten Bogor yang telah berhasil melaksanakan sistem pengendalian intern secara efektif. Hal ini dapat dilihat dari buku laporan evaluasi kinerja selama 3 tahun terakhir yang mengalami peningkatan dan berhasil mendapatkan prestasi terbaik urutan ke-2 se-Indonesia oleh Badan Peningkatan Penyelenggaraan Sistem Penyediaan Air Minum (BPPSPAM) atas Badan Pengawas Keuangan dan Pembangunan. Hasil penelitian ini diharapkan dapat menjadi percontohan bagi pelaksanaan sistem internal oleh stakeholders.
\end{abstract}

Kata Kunci: Sistem Pengendalian; Sistem Manajemen; Pengendalian internal

\begin{abstract}
The internal control system at the Tirta Kahuripan Regional Drinking Water Company (PDAM) in Bogor Regency is implemented to determine whether the management system has been implemented properly or not and to avoid cost leaks. The internal control system implemented in PDAM Bogor Regency in terms of segregation of duties and authorities is still not running optimally with evidence of concurrent positions. It is feared that there will be abuse of office power which will result in fraud. It is hoped that the internal control system can prevent a fraud that will occur. The thing to be achieved in this research is to analyze the effectiveness of the application of the internal control system as an effort to control or even prevent the incidence of fraud. The qualitative method is applied in this research by using data collection techniques that are carried out through observation and interviews (in-depth interviews). The results of this study indicate that PDAM Tirta Kahuripan Bogor Regency has succeeded in implementing the internal control system effectively. This can be seen from the performance evaluation report book for the last 3 years which has increased and succeeded in getting the 2 nd best achievement in Indonesia by the Agency for the Improvement of the Implementation of
\end{abstract}


the Drinking Water Supply System (BPPSPAM) of the Financial and Development Supervisory Agency. The results of this study are expected to become a pilot for the implementation of internal systems by stakeholders.

Keywords: Control System; Management System; Internal Control

\section{PENDAHULUAN}

Dalam pengendalian suatu system manajemen, kecurangan dipengaruhi oleh ada atau tidaknya kesempatan (Opportunity) atau peluang. Salah satu penyebab dari banyaknya kecurangan yang terjadi dikarenakan masih rendahnya pengendalian internal serta kurang maksimalnya fungsi pengawasan. Pengendalian internal adalah representatif dari keseluruhan kegiatan di dalam organisasi yang harus dilaksanakan untuk memberikan keyakinan yang memadai tentang pencapaian tujuan pengendalian operasional yang efektif dan efisien, keandalan laporan keuangan, serta kepatuhan terhadap hukum (Cendikia, et all. 2016).

Pengendalian intern yang dipahami sebagai usaha manajemen dalam menjaga aktiva (kekayaan) organisasi melalui penerapan prosedur tertentu bekerja melalui tiga dimensi dalam menjaga aktiva perusahaan. Pengendalian intern yang baik dan disertai praktek-praktek yang sehat dalam tata kelola keuangan akan menjaga kekayaan perusahaan secara preventive, detektif dan korektif. Lemahnya sistem pengendalian intern dalam manajemen perusahaan terbukti telah banyak mengakibatkan perusahaan berguguran karena tindak kecurangan dan ketidakberesan yang dilakukan oleh manajemen maupun non manajemen (Theodore, 2015).

Salah satu hal yang diperlukan dan merupakan salah satu syarat dari perusahaan yang berkualitas adalah implementasi Good Corporate Governance (GCG). GCG adalah mekanisme yang mengatur hubungan antara manajemen, pemerintah, karyawan, serta para pemegang kepentingan internal dan eksternal lainnya yang berkaitan dengan hak-hak dan kewajiban mereka atau dengan kata lain suatu sistem yang mengendalikan perusahaan (Wahyudin et al, 2014). Tujuan dari tata kelola keuangan ialah untuk menciptakan nilai tambah bagi semua pihak yang berkepentingan (stakeholders). Adapun prinsip-prinsip dari Good Corporate Governance ini meliputi transparasi, kemandirian, akuntabilitas, pertanggung jawaban dan kewajaran (fairness) (Wahyudin et al, 2014).

Perusahaan Daerah Air Minum (PDAM) Tirta Kahuripan Kabupaten Bogor, yang mana sebagai perusahaan daerah yang dituntut untuk selalu profesional dikarenakan PDAM Tirta Kahuripan Kabupaten Bogor wajib menjalankan fungsinya sebagai perusahaan yang produktif. PDAM Tirta Kahuripan Kabupaten Bogor merupakan perusahaan Badan Umum Milik Daerah (BUMD) yang berbentuk Perum dan bergerak dalam hal pengelolaan air bersih dan air minum. Laporan yang dibuat oleh perusahaan setiap akhir tahun adalah laporan kinerja yang di dalamnya terdapat laporan keuangan perusahaan. Laporan yang dibuat wajib menyajikan secara jelas mengenai arus aliran pendanaan, termasuk laba dan rugi, sebagai indikator berjalannya suatu perusahaan. Hal ini dilakukan agar segala tindakan yang dilakukan oleh perusahaan dapat dimonitor dengan baik oleh 
stakeholders melalu system pengendalian intern.

Sistem pengendalian intern pada PDAM Tirta Kahuripan Kabupaten Bogor dilaksanakan untuk memonitor dan mengevaluasi sistem manajemen bekerja dengan baik atau tidak untuk mengindari missleading atau adanya kebcooran dana hasil dari kecurangan yang dilakukan oleh oknum tertentu. Sistem pengendalian intern di PDAM Kabupaten Bogor dalam hal pemisahan tugas dan wewenang masih belum sepenuhnya dilaksanakan sesuai dengan apa yang telah ditetapkan oleh manajemen, seperti adanya posisi yang masih rangkap jabatan. Hal ini dikhawatirkan akan terjadi penyalahgunaan wewenang yang merupakan salah satu bentuk kecurangan. Sistem pengendalian intern sangat diharapkan bisa mencegah sebuah kecurangan yang akan terjadi.

Dalam pengajuan biaya ataupun investasi yang sudah ada pada anggaran tahunan perusahaan, perusahaan khususnya bagian keuangan harus benar-benar teliti dan selektif dalam menerima setiap pengajuan biaya atau investasi. Setiap kecurangan yang akan atau yang telah terjadi, dikarenakan adanya kesempatan (opportunity) atas pemeriksaan pada saat pembuatan anggaran ataupun pengajuan biaya atau investasi.

Penelitian ini diharapkan dapat memberikan sumbangan pemikiran dan informasi yang bermanfaat bagi perusahaan sebagai bahan evaluasi untuk perkembangan dan kemajuan perusahaan.Selain itu, hasil penelitian ini bisa dijadikan bahan pertimbangan Pemerintah Daerah khususnya Kabupaten Bogor dalam mengevaluasi khususnya pelaporan keuangan daerah dari perusahaan milik daerah sesuai dengan Peraturan Bupati Bogor Nomor 8 Tahun 2009 tentang Pokok-Pokok Pengelolaan Keuangan Daerah, dalam pelaksanaan mengelolah keuangan perusahaan milik daerah yang lebih baik, guna mengurangi terjadinya kecurangan pada pengelolahan keuangan perusahaan pemerintah daerah.

Penulisan penelitian ini dibatasi dalam hal melakukan pemantauan pola kerja di bagian Satuan Pengawasan Intern (SPI), secara di dalam ruangan kantor maupun di lapangan. Dan dalam penulisan penelitian ini berkegiatan aktif untuk diskusi atau sharing-sharing dengan staff dan kasie di satuan kerja SPI. Selanjutnya penulisan penelitian ini menggabungkan hasil pemantauan pola kerja, diskusi, dan data-data yang telah penulis dapatkan. Hasil akhirnya dalam penulisan penelitian ini akan digunakan untuk mengetahui seberapa efektiv dari bagian SPI yang sekaligus bertindak sebagai audit internal perusahaan, agar dalam tindakan/indikasi kecurangan dapat tercegah dan apa yang menjadi tujuan perusahaan dapat terwujud.

\section{TINJAUAN PUSTAKA}

\section{Sistem Pengendalian Intern}

Sistem Pengendalian Internal merupakan suatu sistem usaha atau sistem sosial yang dilakukan perusahaan yang terdiri dari struktur organisasi, metode dan ukuran-ukuran untuk menjaga dan mengarahkan jalan perusahaan agar bergerak sesuai dengan tujuan dan program perusahaan agar terdorong efisiensi serta dipatuhinya kebijakan manajemen (Octaviani, 2018).

Menurut Mulyadi (2017:129), sistem pengendalian intern meliputi struktur 
organisasi, cara-cara, dan alat-alat yang dikoordinasikan di dalam perusahaan untuk menjaga keamanan harta (asset) milik perusahaan, mengusut ketelitian dan kebenaran data akuntansi, mengoptimalkan efisiensi operasional, serta menaikkan tingkat pelaksanaan kebijakan manajemen yang telah ditetapkan. Adapun pengertian sistem pengendalian intern menurut AICPA (American Institute of Certified Public Accountants) dalam Lusi (2016), ialah suatu proses yang dipengaruhi oleh dewan komisaris, manajemen, dan satuan usaha yang lainnya guna dirancang untuk mendapatkan keyakinan yang memadai tentang pencapaian tujuan yang mencakup efektifitas dan efisiensi operasi, kehandalan jenis laporan keuangan dalam bentuk-bentuk akuntansi, kesesuaian dengan undang-undang dan hukum yang berlaku.

Sistem pengendalian intern berfungsi untuk pengaturan sumber daya yang tersedia sehingga berfungsi secara maksimal untuk memperoleh selisih dari keuntungan dengan dengan berpedoman pada asas cost dan benefit. Tujuan penerapan sistem pengendalian intern dalam perusahaan adalah menghindari penyimpangan kegiatan atau kebijakan dari prosedur yang telah ditetapkan sehingga laporan keuangan dan fungsi sistem informasi akuntansi yang dihasilkan lebih terpercaya serta kegiatan perusahaan sesuai dengan hukum dan peraturan yang berlaku. Hal ini menunjukkan kinerja suatu perusahaan terutama manajemen mampu menghindari resiko penerapan suatu sistem (Jewel, 2012).

Tujuan Sistem Pengendalian Internal diantaranya merupakan menjaga kekayaaan dan catatan organisasi, melakukan pengecekan ketelitian dan keandalan data akuntansi, mendorong efisiensi dengan menggunakan sumber daya dan sarana. Dan juga bertujuan untuk mendorong dipatuhinya kebijakan manajemen (Furqani, 2016).

\section{Asal Muasal Terjadinya Kecurangan}

Kecurangan adalah suatu pengertian umum yang mencakup beragam cara yang dapat digunakan oleh kecerdikan manusia, yang digunakan oleh seseorang untuk mendapatkan keuntungan dari orang lain melalui perbuatan yang tidak benar (Widjaja, 2012 dalam Ramdhani, 2018). Kecurangan dilakukan untuk memperoleh keuntungan berupa uang dan kekayaan, atau untuk menghindari pembayaran atau kerugian jasa, atau menghindari pajak serta mengamankan kepentingan pribadi atau usaha (Sayyid, 2014).

Dalam teori segitiga fraud, sebuah kecurangan yang dilakukan oleh seseorang atau sekelompok di dalam sebuah organisasi atau perusahaan mempunyai dasar sebuah dorongan yang pada akhirnya kecurangan tersebut dilakukan. Kurniawan (2015), menjelaskan banyak hal tentang dorongandorongan umum terjadinya fraud triangle theory, yaitu:

Tekanan (pressure), adalah segala sesuatu yang dihadapi oleh pelaku kecurangan dan menciptakan kebutuhan mendesak baginya untuk melakukan kecurangan. Kebutuhan mendesak yang dihadapi ini biasanya berkaitan dengan tekanan keuangan berupa hutang dan gaya hidup yang boros namun tidak disertai dengan kemampuan keuangan yang cukup untuk membiayai gaya hidup tersebut. Selain itu, kebiasaan buruk lain seperti mengkonsumsi narkoba dan berjudi juga turut memberikan tekanan bagi seseorang untuk mencari uang melalui tindakan kecurangan. 
Kesempatan (oppurtunity), sangat berkaitan dengan situasi yang memungkinkan seseorang untuk melakukan kecurangan. Kesempatan ini timbul terutama karena lemahnya pengendalian internal yang diterapkan untuk mencegah dan mendeteksi kecurangan. Orang-orang yang telah bekerja lama di dalam sebuah organisasi tentu lebih memahami kelemahan-kelemahan yang ada di dalam pengendalian internal sehingga dapat melakukan kecurangan tanpa dideteksi oleh pengendalian internal.

Kesempatan juga dapat dimiliki apabila orang lain terlalu percaya kepada pelaku kecurangan tanpa memberikan pengawasan yang memadai dengan alasan telah menaruh kepercayaan penuh kepada pelaku kecurangan. Kesempatan juga dapat terjadi karena lemahnya sanksi yang diberikan. Di samping itu tercipta beberapa kondisi lain yang kondusif untuk terjadinya tindakan kecurangan.

Pembenaran (rationalization), adalah pola pikir para pelaku kecurangan yang menjadi alasannya untuk membenarkan tindakan kecurangan yang dilakukannya. Beberapa alasan yang digunakan oleh banyak pelaku kecurangan untuk mencari pembenaran atas perbuatannya, antara lain ; alasan yang pertama adalah pelaku menganggap bahwa yang dilakukan sudah merupakan hal biasa dan sering dilakukan oleh orang lain. Alasan kedua yaitu pelaku merasa berjasa besar terhadap organisasi dan seharusnya ia menerima kompensasi yang telah diterimanya saat ini. Alasan berikutnya adalah pelaku menganggap bahwa ia hanya meminjam dari organisasi dan suatu saat akan dikembalikan. Alasan yang terakhir yaitu pelaku beranggapan bahwa perbuatannya ini tidak melukai siapapun dan hal tersebut hanya merupakan masalah yang kecil saja.

\section{Sistem Pengendalian Intern VS Kecurangan}

Semakin banyak informasi tentang kasus kecurangan yang melibatkan banyak pihak di lingkungan perusahaan maupun di lingkungan pemerintahan. Hal tersebut menggambarkan betapa tindak kecurangan sudah mencapai tingkat yang memprihatinkan. Salah satu penyebab terjadinya tersebut adalah lemahnya sistem pengendalian internal dari suatu organisasi. Dalam suatu manajemen, evaluasi dan pengendalian adalah komponen penting untuk untuk memastikan tujuan yang ingin dicapai oleh sebuah organisasi agar terlaksana dengan baik. Evaluasi dan pengendalian dapat dilaksanakan sendiri oleh manajemen yang disebut pengendalian internal.

Dalam PP No.60 Tahun 2008 Sistem Pengendalian Intern adalah proses yang integral pada tindakan dan kegiatan yang dilakukan secara terus menerus oleh pimpinan dan seluruh pegawai untuk memberikan keyakinan memadai atas tercapainya tujuan organisasi melalui kegiatan yang efektif dan efisien, keandalan pelaporan keuangan, pengamanan aset negara, dan ketaatan terhadap peraturan perundang-undangan. Penerapan Sistem Kendali Kecurangan telah dilakukan sejak tahun 2012. Istilah ini diadaptasi dari sistem yang telah berjalan di negara-negara lain yang biasanya menggunakan istilah Fraud Control Plan, Australian National Audit Office Fraud Control Strategies, dan lain-lain.

\section{Penelitian Terdahulu}

Adapun dalam penelitian ini akan disampaikan hasil pengkajian dari beberapa penelitian terdahulu, antara lain : 
Kajian Optimalisasi Peran Auditor Internal Dalam Penerapan Sistem Anti Fraud (Studi kasus Bank Sleman). Disusun oleh Dwi Handoyo Miharjo pada tahun 2018. Potensi kecurangan menjadi sebuah polemik pada perusahaan khususnya di dunia perbankan. Penerapan anti fraud sudah berjalan baik dengan mendeteksi risiko yang ada pada setiap unit kerja. Dengan adanya pelatihan dan pendidikan guna memberikan pemahaman terhadap fraud pada setiap karyawan.

Deteksi Fraud Pada Sektor Pemerintahan. Disusun oleh Atrisia Inayati Mamahit pada tahun 2018. Penelitian ini menggunakan metode wawancara langsung di lapangan pada 12 informan yang bertugas sebagai pemeriksa di BPKP Perwakilan Jawa Tengah. Fraud menjadi perhatian utama di sektor pemerintahan karena tidak kunjung selesai pada setiap tahunnya. Korupsi menempati posisi pertama dari jenis fraud yang paling banyak diketemukan. Salah satu sumber informasi adalah berasal dari whistle-blowing, karena setiap pegawai atau karyawan bahkan masyarakat secara luas dapat melaporkan adanya tindakan fraud yang terjadi pada sektor pemerintahan dapat terinformasikan.

Pengaruh Tekanan, Keefektifan Sistem Pengendalian Internal, Perilaku Tidak Etis dan Jabatan Dalam Pengelolaan Keuangan Terhadap Fraud (Studi pada Satuan Kerja Perangkat Daerah Kota Metro). Disusun oleh Ardi Irphani pada tahun 2017. Tindakan korupsi pada pemerintahan saat ini kondisinya sangat memprihatinkan khususnya yang menjadi bagian dari fraud dalam akuntansi. Korupsi yang terjadi merambah hingga ke sektor pendidikan seperti pembangunan sekolah dan bantuan operasional sekolah (BOS). Sehingga penelitian ini berfokus pada pengaruh tekanan, sistem pengendalian internal, perilaku tidak etis dan jabatan dalam mengantisipasi terjadinya fraud.

Berdasarkan rumusan masalah, pertanyaan riset dan proposisi yang telah dibangun sebelumnya, maka model analisis penelitian ini dimulai dari menganalisis sistem pengendalian intern terhadap pencegahan (preventif) kecurangan dengan menganalisis aplikasi dari sistem-sistem pengendalian yang diterapkan oleh BPKP selaku APIP serta sejauh mana keefektifan dari fungsi sistem-sistem pengendalian tersebut untuk mencegah terjadinya kecurangan. Gambar 1 merupakan kerangka konseptual penelitian ini.

\section{Gambar 1. Efektivitas Sistem Pengendalian Intern}

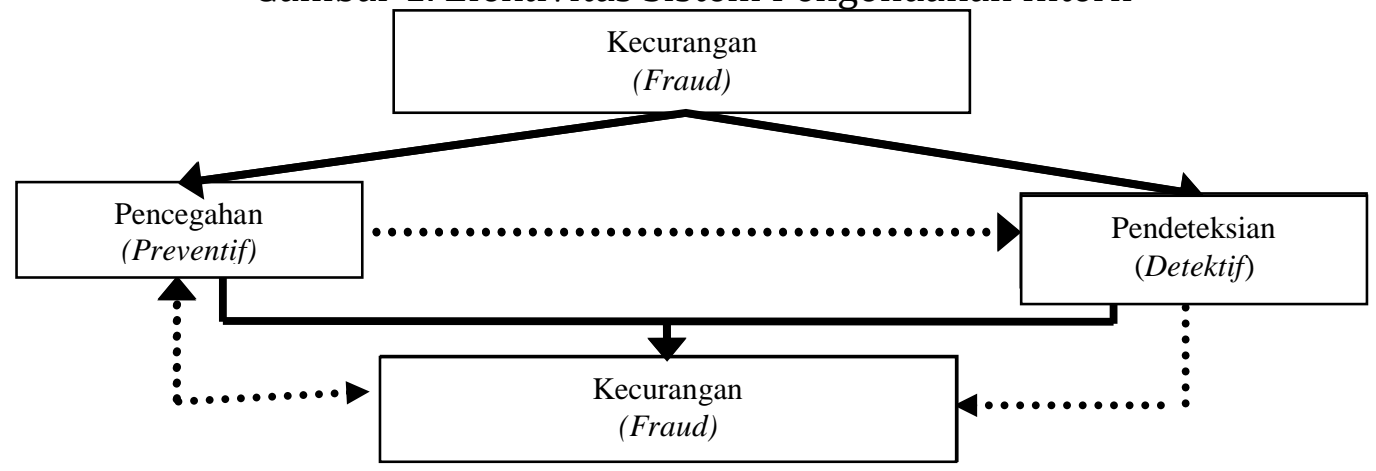

Sumber: Data Diolah Peneliti (2020)

Setelah menganalisis aplikasi dan keefektifan fungsi dari sistem pencegahan kecurangan, kemudian dilakukan analisis terhadap metode-metode pendeteksian kecurangan yang merupakan penerapan sistem pengendalian intern baik secara 
aplikasi maupun keefektifan fungsinya. Bila suatu kecurangan dapat terdeteksi secara dini, maka sistem pendeteksian akan memberi feedback terhadap sistem pencegahan (menandakan bahwa sistem pengendalian berjalan dengan baik), sehingga kecurangan yang berpotensi untuk memberikan kerugian yang lebih besar dapat ditangkal lebih awal.

\section{METODOLOGI PENELITIAN}

Metode penelitian yang diterapkan dalam penelitian ini adalah deskriptif kualitatif yang fokus pada penjabaran hasil dari observasi dari sumber. (Moleong, 2015:8). Pendekatan dalam penelitian ini akan menggunakan bagian deskriptif yang membahas esensi dari pengalaman yang dialami individu.

Dalam penelitian ini menceritakan proses, dan ditambah dengan adanya informan yang digunakan pada mendukung penelitian. Tabel 1 menunjukkan informan yang digunakan oleh peneliti yaitu, 3 (tiga) Kepala Sub. Bagian pada satuan kerja SPI. Yang pertama bapak Ibrar selaku Kasie Adm \& SDM dengan harapan yang bisa memberikan jawaban atas segala bentuk pengadministrasian dan kepegawaian yang ada di perusahaan. Kedua adalah dengan bapak Isyraf selaku Kasie Pengawasan Operasional dengan tujuan bisa memberikan informasi perihal kegiatan operasional yang terjadi di perusahaan. Dan yang terakhir dengan bapak Asep selaku Kasie Pengawasan Fisik yang akan membantu dalam menginformasikan semua pekerjaan fisik, seperti pemasangan sambungan baru, kerjasama, dan pengadaan barang.

Metode pengumpulan data yang digunakan adalah melalui observasi (observation) dan wawancara (in-depth interview) pada bab selanjutnya dalam daftar wawancara. Teknik pengumpulan data yang digunakan pada penelitian ini mengacu pada Creswell (2016), untuk memudahkan peneliti dalam mengumpulkan data untuk dimasukkan dalam analisis data dan pembahasan dalam penelitian kualitatif.

Tabel 1. Informan Penelitian

\begin{tabular}{llc}
\hline \multicolumn{1}{c}{ Nama } & \multicolumn{1}{c}{ Kualifikasi Keahlian } & Satuan Kerja \\
\hline Ibrar & Kasie Admin \& SDM & SPI \\
Isyraf & Kasie Pengawasan Oprs & SPI \\
Asep & Kasie Pengawasan Fisik & SPI \\
\hline
\end{tabular}

Sumber: Data Diolah Peneliti (2020)

*Catatan : Nama informan bukan nama sebenarnya.

Selanjutnya, peneliti menggunakan triangulasi sebagai teknik untuk mengecek keabsahan data. Dimana dalam pengertiannya triangulasi adalah teknik pemeriksaan keabsahan data yang memanfaatkan sesuatu yang lain dalam membandingkan hasil wawancara terhadap objek penelitian (Moloeng, 2015).

Sedangkan Teknik analisis data dalam penelitian ini mengikuti konsep yang diberikan Miles dan Huberman (1992) dalam Sugiyono (2015) dan dalam Sonjaya (2017), yaitu model analisis data yang dilakukan secara interaktif dan berlangsung terus menerus sampai tuntas, sehingga datanya sudah jenuh. Aktivitas dalam 
analisis data, yaitu reduksi data, penyajian data, dan penarikan kesimpulan.

\section{HASIL DAN PEMBAHASAN}

Penelitian ini mendapatkan persetujuan dari pihak Satuan Pengawasan Intern (SPI) yang bertindak sebagai audit internal perusahaan, dan berhasil mendapatkan dokumen yang menjadi dasar program kerja satuan kerja SPI. Dokumen berupa pedoman mutu sangatlah penting untuk pelaksanaan kinerja di satuan kerja SPI, untuk mengidentifikasi resiko dan peluang yang ada di PDAM agar bisa maksimal dalam melakukan tugas terutama dalam hal pencegahan tindakan kecurangan. Adapun dokumen yang lainnya adalah prosedur kerja SPI, yang mana dokumen tersebut memetakan langkah-langkah kerja SPI dalam pelaksanaan kinerja perusahaanyang nantinya akan dilakukan pelaporan pada direksi. Prosedur pemeriksaan khusus juga berhasil peneliti dapatkan, yang mana di dalamnya terdapat langkah-langkah yang ditempuh oleh satuan kerja SPI bilamana mendapatkan temuan adanya penyimpangan/pelanggaran.

Auditor independen atau auditor eksternal akan bekerja sama dengan satuan kerja SPI dalam hal bagaimana sistem pengendalian intern di perusahaan benar-benar dapat berjalalan dengan efektif dan efisien, sehingga peluang untuk menimbulkan suatu kecurangan akan dapat dilakukan pencegahannya. Audit internal perusahaan merancang dan membuat berupa evaluasi kinerja, yang nantinya akan dilakukan penilaian oleh auditor eksternal atas evaluasi kinerja dari audit internal perusahaan.

Manajemen mendapatkan informasi dari audit internal sebagai pengambilan keputusan dengan dasar laporan hasil audit tersebut. Kondisi yang ditemukan adalah sesuai dalam penjelasan kasie admin keuangan dan SDM pertimbangan atas pengendalian intern bahwa pemantauan sudah berjalan dengan baik. Sehubungan juga daripada kondisi yang ditemukan pada wawancara yang peneliti lakukan, maka dapat dinyatakan bahwa tugas yang dilakukan eksekutor kecurangan adalah melakukan tindakan dikarenakan pihak/seseorang bertindak tidak sesuai dengan standar operasional prosedur (SOP) yang ditetapkan manajemen. Pihak yang bertugas sebagai pengawas sekaligus penanggungjawab disini adalah bagian pengawasan melekat (waskat) yang seharusnya dapat mencegah kecurangan tersebut terjadi. Maka integritas pada diri pegawai seharusnya dipertahankan untuk mendapatinya tujuan perusahaan dapat berjalan sesuai dengan yang telah ditetapkan.

Satuan pengawasan intern mempunyai Pedoman Mutu, sama halnya satuan kerja yang lainnya juga memiliki. Identifikasi resiko dan peluang di bagian satuan pengawasan intern terhadap mutu layanan PDAM Tirta Kahuripan Kabupaten Bogor, untuk menentukan jenis/bentuk pengendalian atas resiko/tindak lanjut. Adapun prosedur pada SPI bertujuan untuk memastikan pelaksanaan kegiatan perusahaan pada seluruh unit kerja/satuan kerja sudah sesuai dengan kriteria yang telah ditetapkan. Ruang lingkup prosedur berlaku pengawasan intern pada seluruh unit kerja di PDAM Tirta Kahuripan Kabupaten Bogor. Adapun rincian kegiatan prosedur yang dilakukan oleh pihak SPI, antara lain pengajuan program kerja anggaran. Kemudian pelaksanaan program kerja, selanjutnya melakukan 
pelaksanaan pengawasan, dan yang terakhir pembuatan pelaporan.

Dalam pengajuan program kerja anggaran, kepala SPI membuat rencana kerja anggaran sesuai dengan program kerja yang akan dilaksanakan pada tahun anggaran tertentu. Masing-masing kepala bagian unit kerja/satuan kerja, membuat rencana kerja/program kerja untuk 1 tahun anggaran mengacu pada RKAP. Setelah program kerja selesai dibuat, kemudian pengajuan pengesahan ke Direktur Utama.

Pelaksanaan program kerja yang telah dibuat, maka pada tahun anggaran yang telah ditetapkan, SPI melaksanakan pengawasan ke seluruh cabang dan bagian terlebih dahulu membuat surat pengajuan beserta biayanya ke Direktur Utama. Sebelum melakukan pengawasan, pihak SPI juga membuat surat pemberitahuan ke masing-masing bagian dan cabang. Pengawasan ke tiap-tiap cabang dan bagian, membandingkan data yang ada dengan kondisi yang ada dilapangan sebenarnya.

Setelah selesai kegiatan pengawasan di setiap cabang dan bagian, SPI membuat rekap hasil pengawasan dan membuat surat berita acara, serta mempresentasikan hasil-hasil pengawasan kepada unit kerja terkait. Kepala bidang pengawasan selaku penanggung jawab pelaksanaan kegiatan pengawasan membuat laporan pertanggung jawaban kepada kepala SPI, kemudian kepala SPI membuat laporan pertanggung jawaban kepada Direktur Utama terkait pengawasan program kerja yang telah dilaksanakan.

Bilamana satuan pengawasan intern (SPI) menemukan yang mengandung unsur-unsur yang merugikan perusahaan, maka SPI melakukan tindakan prosedur pemeriksaan khusus dan pelakunya dapat diberikan sanksi sesuai dengan peraturan yang berlaku di perusahaan PDAM Tirta Kahuripan Kabupaten Bogor. Adapun macam temuan laporan/pengaduan dari pegawai, pelanggan, maupun dari masyarakat umum antara lain tentang dugaan indisipliner, penyalahgunaan wewenang/jabatan, sambungan illegal, dan lain sebagainya, yang merugikan perusahaan atau masyarakat baik material ataupun immaterial yang dilakukan oleh pegawai PDAM Tirta Kahuripan Kabupaten Bogor. Hasilnya tersebut akan dilaporkan oleh kepala SPI kepada Direksi, dengan disposisi direktur utama memerintahkan kepala SPI untuk melaksanakan pengecekan dan memproses dengan peraturan yang berlaku apabila benar terjadi pelanggaran oleh pegawai yang sesuai dengan laporan/pengaduan.

Berdasarkan disposisi direksi, kepala SPI memerintahkan kepala bidang pengawasan untuk melaksanakan pengecekan kelapangan dengan disertai datadata yang mendukung. Kepala bidang pengawasan beserta staf yang ditunjuk untuk bertugas, melakukan pemeriksaan kondisi di lapangan dengan berdasarkan data-data yang ada. Pemeriksaan hasilnya dibuatkan berita acara yang ditanda tangani oleh pelanggan atau pegawai yang dilakukan pemeriksaan, kemudian kepala bidang pengawasan membuat laporan kepada kepala SPI.

Kepala SPI membuat undangan dengan tembusan direksi, kepala bagian SDM dan atasan yang bersangkutan, pemanggilan berdasarkan laporan dari kepala bidang pengawasan untuk klarifikasi terhadap pegawai yang diduga melakukan pelanggaran dengan memberikan beberapa pertanyaan yang telah tertulis dan membuatkan surat pernyataan bermaterai. Setelah itu dibuatkan laporan oleh kepala SPI dengan berdasarkan bukti-bukti yang ada, laporan tersebut berisi dasar 
laporan, kondisi dan fakta yang ditemukan, bukti hasil pemeriksaan, serta kesimpulan berupa rekomendasi yang berisi sanksi pembinaan sesuai dengan peraturan PDAM Tirta Kahuripan Kabupaten Bogor. Laporan ditujukan untuk direktur utama dengan tembusan kepada direktur umum dan direktur operasional serta kepala bagian SDM. Sistem pengendalian intern yang efektif diaplikasikan pada sebuah perusahaan, akan mempunyai dampak baik yang signifikan. Mulai dari segi keuangan, pelayanan, operasi, hingga sumber daya manusia (SDM). Tabel 2 menunjukkan daftar pertanyaan yang disampaikan dan jawaban yang disampaikan para informan pada penelitian ini.

Tabel 2. Daftar Wawancara Narasumber PDAM Tirta Kahuripan Kabupaten Bogor

\begin{tabular}{|c|c|c|}
\hline No & Pertanyaan & Jawaban \\
\hline 1 & $\begin{array}{l}\text { Apa saja yang menjadi rutinitas } \\
\text { agenda kerja oleh Satuan Pengen- } \\
\text { dalian Internal (SPI)? (Bapak } \\
\text { Ibrar) }\end{array}$ & $\begin{array}{l}\text { Menyusun dan melaksanakan Rencana Kerja } \\
\text { dan Anggaran Perusahaan (RKAP) bersama } \\
\text { masing-masing satuan kerja yang terkait. }\end{array}$ \\
\hline 2 & $\begin{array}{l}\text { Dalam hal evaluasi ke setiap } \\
\text { cabang ataupun satuan kerja } \\
\text { perihal realisasi kerja, apakah } \\
\text { setiap bulan atau ada periode } \\
\text { berapa bulan sekali? (Bapak } \\
\text { Ibrar) }\end{array}$ & $\begin{array}{l}\text { Mengevaluasi serta melaporkan realisasi kerja } \\
\text { dan anggaran tahunan setiap triwulan dari } \\
\text { masing-masing satuan kerja maupun kantor } \\
\text { cabang }\end{array}$ \\
\hline 3 & $\begin{array}{l}\text { Bagaimana dengan sistem pe- } \\
\text { ngendalian intern di PDAM Tirta } \\
\text { Kahuripan? (Bapak Isyraf) }\end{array}$ & $\begin{array}{l}\text { Sistem pengendalian intern di PDAM Tirta } \\
\text { Kahuripan berjalan pada setiap kegiatan atau } \\
\text { satuan kerja, agar tidak menyimpang dari apa } \\
\text { yang menjadi tujuan perusahaan. }\end{array}$ \\
\hline 4 & $\begin{array}{l}\text { Apakah terdapat kebijakan } \\
\text { tertulis mengenai kedisiplinan } \\
\text { yang ditetapkan oleh perusa- } \\
\text { haan? (Bapak Ibrar) }\end{array}$ & $\begin{array}{l}\text { Sistem pengendalian intern di PDAM Tirta } \\
\text { Kahuripan sudah tertuang dalam SK Direksi. }\end{array}$ \\
\hline 5 & $\begin{array}{l}\text { Bagaimana kebijakan dan gaya } \\
\text { operasi manajemen mendukung } \\
\text { efektivitas dalam pencapaian tu- } \\
\text { juan perusahaan? (Bapak Isyraf) }\end{array}$ & $\begin{array}{l}\text { Pihak manajemen mendukung setiap kegiatan } \\
\text { operasional perusahaan, agar apa yang } \\
\text { menjadi tujuan perusahaan bisa tercapai } \\
\text { dengan efektif. }\end{array}$ \\
\hline 6 & $\begin{array}{l}\text { Apakah laporan mengenai } \\
\text { adanya suatu penyimpangan } \\
\text { yang diterima karyawan selalu } \\
\text { ditindaklanjuti oleh atasan yang } \\
\text { berwenang? (Bapak Ibrar) }\end{array}$ & $\begin{array}{l}\text { Iya, setiap bentuk penyimpangan akan selalu } \\
\text { ditindak lanjuti oleh kepala bagian satuan } \\
\text { kerja terkait hingga selesai. }\end{array}$ \\
\hline 7 & $\begin{array}{l}\text { Apakah penempatan karyawan } \\
\text { baru berdasarkan keterampilan, } \\
\text { keahlian dan pendidikan yang di- } \\
\text { milikinya? (Bapak Ibrar) }\end{array}$ & $\begin{array}{l}\text { Karyawan baru yang diterima di perusahaan } \\
\text { akan ditempatkan pada posisi yang sesuai } \\
\text { dengan pendidikan dan keahlian yang dimiliki } \\
\text { karyawan tersebut. }\end{array}$ \\
\hline 8 & $\begin{array}{l}\text { Apakah perusahaan mempunyai } \\
\text { struktur organisasi yang meng- } \\
\text { gambarkan garis wewenang dan } \\
\text { tanggung jawab yang jelas? } \\
\text { (Bapak Ibrar) }\end{array}$ & $\begin{array}{l}\text { Itu sudah pasti kita mempunyai hal tersebut, } \\
\text { karena kita selalu dalam pengawasan } \\
\text { Pemerintah Daerah. }\end{array}$ \\
\hline
\end{tabular}




\begin{tabular}{cl}
\hline No & \multicolumn{1}{c}{ Pertanyaan } \\
\hline 9 & $\begin{array}{l}\text { Apakah manajemen menetapkan } \\
\text { resiko sebagai bagian dari pelak- } \\
\text { sanaan pengendalian internal? } \\
\text { (Bapak Isyraf) }\end{array}$ \\
\hline 10 & $\begin{array}{l}\text { Apakah batas waktu yang telah } \\
\text { ditentukan selalu ditaati dalam } \\
\text { pertanggungjawaban uang muka? } \\
\text { (Bapak Isyraf) }\end{array}$ \\
\hline 11 & $\begin{array}{l}\text { Apakah manajemen menetapkan } \\
\text { resiko apabila tindakan perbai- } \\
\text { kan gagal dilakukan? (Bapak }\end{array}$ \\
& Isyraf) \\
\hline 12 & $\begin{array}{l}\text { Apakah dokumen uang muka } \\
\text { yang digunakan telah diberikan } \\
\text { nomor urut cetak? (Bapak Ibrar) }\end{array}$ \\
\hline 13 & $\begin{array}{l}\text { Apakah setiap pengambilan dan } \\
\text { pertanggung jawaban uang muka } \\
\text { oleh satuan kerja yang terkait } \\
\text { mempunyai bukti dokumen? } \\
\text { (Bapak Ibrar) }\end{array}$
\end{tabular}

14 Apakah setiap transaksi yang terjadi diotorisasi oleh pihak yang berwenang? (Bapak Ibrar)

15 Apakah terdapat sistem informasi akuntansi yang memadai yang dapat memastikan kelengkapan pencatatan transaksi? (Bapak Ibrar)

16 Apakah terdapat prosedur dalam melaksanakan berbagai kegiatan dalam perusahaan? (Bapak Isyraf)

17 Apakah monitoring dilakukan oleh orang yang independen? (Bapak Isyraf)

18 Apakah pengendalian yang ada telah didokumentasikan dalam bentuk prosedur penjelasan bagan arus (flowchart) atau bentuk lain? (Bapak Ibrar)
Jawaban

Manajemen telah menetapkan resiko pada setiap pelaksanaan pengendalian intern, yang mana telah tertuang dalam SK Direksi.

Perihal uang muka sampai sejauh ini dalam pertanggung jawaban, masih ada beberapa satuan kerja membuat laporan lebih dari waktu yang telah ditentukan.

Pihak manajemen sudah pasti telah menetapkan resiko apabila tindakan perbaikan gagal dilakukan, yaitu surat teguran, dan atau akan dikenakan sanksi administrasi.

Setiap uang muka yang diterbitkan oleh bagian keuangan, mempunyai nomor urut cetak sesuai dengan pada saat pengajuan.

Setiap pengambilan uang muka, wajib memberikan surat tugas dari kepala bagian yang terkait. Dan ketika memberikan pertanggung jawaban, satuan kerja terkait wajib melampirkan bukti-bukti transaksi dan bukti dokumen voucher atas uang muka yang dimaksud.

Setiap transaksi yang terjadi sudah pasti diotorisasi oleh pihak yang berwenang selain itu juga selalu diketahui oleh Direktur Umum.

Untuk memastikan pencatatan transaksi, di perusahaan menggunakan aplikasi SIKOMPAK. Yang mana memudahkan dalam mengintergrasi setiap transaksi ke dalam sistem informasi akuntansi.

Setiap kegiatan yang dilakukan di PDAM Tirta Kahuripan Kabupaten Bogor harus sesuai dengan prosedur yang telah ditetapkan dalam SK Direksi

Untuk proses monitoring dilakukan oleh kami yaitu Satuan Pengendalian Internal, yang bertindak langsung dalam pelaporan pada Direksi.

Seperti yang telah disampaikan, bahwa di PDAM Tirta Kahuripan Kabupaten Bogor untuk setiap pengendalian telah diatur dan tertuang dalam SK Direksi.

19 Apakah inspeksi mendadak dilakukan oleh pimpinan perusahaan untuk memastikan bahwa pengendalian internal telah ber-

Inspeksi mendadak dilakukan Direksi dan bahkan oleh Dewan Pengawas, untuk memastikan langsung di lapangan bahwa sistem dan prosedur telah dijalankan dengan 


\begin{tabular}{llll}
\hline No & \multicolumn{1}{c}{ Pertanyaan } & Jawaban \\
\hline & jalan sebagaimana mestinya? & baik dan benar. & \\
\hline (Bapak Isyraf) & Apakah telah dilakukan perbai- & Setiap bulan bagian keuangan akan \\
kan terhadap berbagai kelemah- & memeberikan laporan terkait rekap uang \\
an dalam pengendalian internal & muka dari berbagai kode akun dan di setiap \\
perusahaan atas uang muka? & bagian satuan kerja, agar kita bisa bersama- \\
(Bapak Ibrar) & sama memberikan informasi ke bagian satuan \\
& kerja terkait bilamana telah melebihi dari \\
& batas waktu yang telah ditentukan dalam \\
& prosedur. Agar bisa segera memberikan \\
& laporan uang muka yang dimaksud oleh \\
& bagian terkait satuan kerja tersebut. \\
\hline
\end{tabular}

Sumber: Data Diolah Peneliti (2020)

Dalam hal mencegah kecurangan di Perusahaan Daerah Air Minum Tirta Kahuripan Kabupaten Bogor yang telah mengefektifkan sistem pengendalian intern khususnya, pada Tabel 3 dapat dilihat evaluasi kinerja selama 3 tahun kebelakang dari tahun 2016, 2017, dan 2018, tiap tahun mengalami peningkatan total nilai kinerja yang di tahun 2016 nilai kinerja 3,97. Untuk tahun 2017 total nilai kinerja mengalami peningkatan 0,13 dari tahun sebelumnya yaitu dengan nilai 4,10. Pada tahun 2018 terus melanjutkan perkembangannya dengan meraih total nilai kinerja 4,19 dan berhasil mendapatkan prestasi terbaik urutan ke-2 seIndonesia oleh Badan Peningkatan Penyelenggaraan Sistem Penyediaan Air Minum (BPPSPAM) atas Badan Pengawas Keuangan dan Pembangunan.

Tabel 3 menunjukkan bahwa Return on Equity (ROE) perusahaan sempat mengalami penurunan di tahun 2017 dari tahun sebelumnya, namun di tahun 2018 perusahaan berhasil meningkatkan bahkan prosentasenya lebih tinggi daripada di tahun 2016. Hal tersebut dikarenakan rasio operasi keuangan perusahaan lebih diperketat dalam seleksi pembiayaan dan berinvestasi.Dalam hal likuiditas, kas perusahaan dan investasi jangka pendek perusahaan banyak yang menganggur di tahun 2016 dan tahun 2017. Jadi kemampuan perusahaan dalam memenuhi kewajiban keuangan pada saat ditagih dinyatakan sangat mampu untuk membayar kewajiban keuangan secara tepat waktu. Begitupun juga dalam hal solvabilitas atau kemampuan perusahaan untuk membayar hutang-hutangnya, PDAM Tirta Kahuripan sangat mampu untuk membayar hutang-hutangnya kepada kreditor, dikarenakan nilai aktiva melebihi nilai hutang.

Sedangkan untuk kategori kinerja di bidang pelayanan dan operasi, tahun 2017 memperoleh peningkatan dari tahun 2016. Di tahun 2018, perusahaan mampu tetap mempertahankan bobot nilai kinerja seperti pada tahun 2017. Menjaga untuk tetap terus memperbaiki dalam tingkat penyelesaian pengaduan dan kualitas air pelanggan, merupakan salah satu contoh bentuk pengendalian dalam bidang pelayanan. Pelanggan merasa puas dengan kecepatan respon dan terselesainya aduan tersebut, serta kualitas air yang mengalir ke pelanggan tetap baik. Dalam bidang operasi, tingkat kehilangan air terus berusaha diperbaiki dan ditingkatkan agar tidak berdampak pada laba perusahaan. Tekanan sambungan pelanggan dan penggantian meter air, merupakan saling berhubungan. Dimana bentuk pengendaliannya adalah jika tekanan sambungan air tetap kuat dan 
penggantian meter air selalu dilakukan secara berkala, maka itupun juga akan berdampak pada kepuasan pelanggan dan akan berdampak pula pada laba perusahaan.

Penilaian dari segi sumber daya manusia, perusahaan mampu pertahankan kemampuan untuk bisa mendapatkan nilai yang sama pada tahun 2017 sama dengan di tahun 2016. Namun di tahun 2018, perusahaan meningkatkan kompetensi pegawai dengan cara membuat banyak kegiatan diklat pegawai. Sehingga di tahun 2018 perusahaan dapat memperoleh penilaian yang meningkat daripada tahun sebelumnya, yaitu tahun 2017.Maka secara keseluruhan, total nilai kinerja perusahaan PDAM Tirta Kahuripan Kabupaten Bogor dari tahun 2016 ke tahun 2018 selalu mengalami peningkatan kinerja dengan pastinya mendapatkan reward kategori perusahaan SEHAT. Sehingga hasil suatu sistem pengendalian intern di PDAM Tirta Kahuripan Kabupaten Bogor yang telah dijalankan, boleh dikatakan telah efektif dalam mencegah tindakan kecurangan yang akan terjadi di perusahaan.

Tabel 3. Kategori Kinerja

\begin{tabular}{|c|c|c|c|c|c|c|}
\hline \multicolumn{7}{|c|}{ PDAM Tirta Kahuripan Kabupaten B } \\
\hline & \multicolumn{2}{|c|}{2016} & \multicolumn{2}{|c|}{2017} & \multicolumn{2}{|c|}{2018} \\
\hline & Kondisi & Nillal & Kondisi & Nillai & Kendisi & Nillal \\
\hline \multicolumn{7}{|l|}{ A.KEUANGAN } \\
\hline \multicolumn{7}{|l|}{ 1. Rentabilitas } \\
\hline a.ROE & $10,42 \%$ & 5 & $9,35 \%$ & 4 & $12,05 \%$ & 5 \\
\hline b. Ratio Operasi & 0,78 & 3 & 0,81 & 3 & 0,75 & 3 \\
\hline \multicolumn{7}{|l|}{ 2, Uikulditas } \\
\hline a. Ratio Kas & $295,41 \%$ & 5 & $258,73 \%$ & 5 & $113,88 \%$ & 5 \\
\hline b. Efektivitas Penagihan & $98,75 \%$ & 5 & $96,49 \%$ & 5 & $96,78 \%$ & 5 \\
\hline 3. Solvabillitas & $1007,86 \%$ & 5 & $1090,15 \%$ & 5 & $805,61 \%$ & 5 \\
\hline Bobot Kinerja - Bidang Keuangan & \multicolumn{2}{|c|}{1,14} & \multicolumn{2}{|c|}{1,09} & \multicolumn{2}{|c|}{$\mathbf{1 , 1 4}$} \\
\hline \multicolumn{7}{|l|}{ B.PELANANAM } \\
\hline 1.Cakupan Pelayanan & $26,03 \%$ & 2 & $30,87 \%$ & 2 & $29,43 \%$ & 2 \\
\hline 2. Perturmbuhan Pelanggan & $5,00 \%$ & 2 & $6,45 \%$ & 3 & $7,71 \%$ & 3 \\
\hline 3. Tingkat Penyelesalan Pengaduan & $100,00 \%$ & 5 & $100,00 \%$ & 5 & $100,00 \%$ & 5 \\
\hline 4. Kualitas Air Pelanggan & $100,00 \%$ & 5 & 100,0096 & 5 & $100,00 \%$ & 5 \\
\hline 5. Kensumsi Alr Domestik & 17,32 & 2 & 16,36 & 2 & 15,71 & 2 \\
\hline Bobot Kinerja - Bidang Pelayanan & \multicolumn{2}{|c|}{0,80} & \multicolumn{2}{|c|}{0,85} & \multicolumn{2}{|c|}{0,85} \\
\hline \multicolumn{7}{|l|}{ C. OPERASI } \\
\hline 1. Effisiensi Produksi & $78,81 \%$ & 3 & $80,65 \%$ & 4 & $80,06 \%$ & 4 \\
\hline 2. Tingkat Kehllangan air & $27,67 \%$ & 4 & $28,28 \%$ & 4 & $28,36 \%$ & 4 \\
\hline 3. Jam Operasi Layanan / harl & 24 & 5 & 24 & 5 & 24 & 5 \\
\hline 4. Tekanan Sambungan Pelanggan & $79,05 \%$ & 4 & $80,03 \%$ & 5 & $81,31 \%$ & 5 \\
\hline 5. Penggantian Meter Alr & $20,15 \%$ & 5 & $20,01 \%$ & 5 & $25,10 \%$ & 5 \\
\hline Bobot KInerja - Bidang Operasi & \multicolumn{2}{|c|}{1,48} & \multicolumn{2}{|c|}{1,61} & \multicolumn{2}{|c|}{1,61} \\
\hline \multicolumn{7}{|l|}{ D. SDM } \\
\hline 1. Rasie juml peg/1000 plg & 4,93 & 5 & 4,80 & 5 & 4,46 & 5 \\
\hline 2. Ratio diklatpegawai/peningkatan kompetensi & $67,95 \%$ & 4 & $70,92 \%$ & 4 & $91,46 \%$ & 5 \\
\hline 3. Blaya Diklat terhadap Blaya Pegawal & $1,23 \%$ & 1 & $1,49 \%$ & 1 & $2,13 \%$ & 1 \\
\hline Bobot KInerja - Bidang SDM & \multicolumn{2}{|c|}{0,55} & \multicolumn{2}{|c|}{0,55} & \multicolumn{2}{|c|}{0,59} \\
\hline TOTAL NILAI KINERJA & \multicolumn{2}{|c|}{3,97} & \multicolumn{2}{|c|}{4,10} & \multicolumn{2}{|c|}{4,19} \\
\hline KATEGOAI & \multicolumn{2}{|c|}{ SEHAT } & \multicolumn{2}{|c|}{ SEHAT } & \multicolumn{2}{|c|}{ SEHAT } \\
\hline
\end{tabular}

Sumber: laporan Evaluasi Kinerja PDAM Tahun Buku 2018 (2018)

\section{SIMPULAN}

Sistem pengendalian internal secara keseluruhan di PDAM Tirta Kahuripan Kabupaten Bogor sudah terlaksana dengan efektif. Lima komponen pengendalian internal yang sudah dijelaskan pada bab sebelumnya, efektif dalam mencegah kecurangan yang akan terjadi di PDAM Tirta Kahuripan Kabupaten Bogor sehingga membuat perusahaan maksimal dalam kinerja sampai akhirnya bisa meraih 
peringkat ke-2 se-Indonesia oleh BPPSPAM. Setiap pegawai memiliki uraian tugas dan fungsi serta wewenang yang sesuai dengan tanggungjawabnya. Tahapan penilaian resiko yang dimulai dengan mengidentifikasi, kemudian menganalisis, dan terakhir pada tahap pengelolaan resiko belum sampai pada level aktivitas. Penilaian resiko dilakukan penyampaian secara implisit oleh Kasie Admin Keuangan dan SDM, dan staff di Satuan Pengawasan Intern.

Komunikasi yang terjalin sudah sangat baik dengan memanfaatkan era digital, dimana smartphone tidak hanya digunakan sebagai alat komunikasi melainkan juga digunakan sebagai alat tukar informasi yang cepat, efektif dan efisien tanpa harus menyampaikan secara tatap muka langsung. Pada akhir tahun PDAM Tirta Kahuripan selalu membuat laporan buku kinerja, yang di dalamnya terdapat laporan keuangan perusahaan berupa Neraca, Laba Rugi, Arus Kas, dan Ekuitas. Laporan tersebut akan di-audit oleh auditor independent dari suatu Kantor Akuntan Publik yang akan memberikan suatu opini Wajar Tanpa Pengecualian. Setelah itu pihak BPKP akan mengevaluasi laporan dari hasil audit untuk membuat buku kinerja dengan menyatakan bahwa PDAM Tirta Kahuripan Kabupaten Bogor adalah PDAM Sehat.

Semakin baik sistem pengendalian internal dengan implementasinya maka akan semakin baik pula terhadap kualitas laporan buku kinerja PDAM Tirta Kahuripan Kabupaten Bogor. Semakin tinggi akuntabilitas yang ada dalam setiap personal pegawai PDAM Tirta Kahuripan Kabupaten Bogor, akan dapat mempertahankan dan bahkan meningkatkan.

Beberapa hal yang dapat disarankan berdasarkan hasil analisis pada bab sebelumnya tentang sistem pengendalian intern dalam mencegah kecurangan antara lain adalah nilai etika yang baik sangat perlu teraplikasi oleh seluruh pegawai, sebagai contoh kedisplinan waktu dan kehadiran. Dalam hal pelatihan untuk meningkatkan kemampuan sumber daya manusia lebih tepat sasaran. Di PDAM Tirta Kahuripan Kabupaten Bogor diperlukan adanya identifikasi resiko secara eksplisit sampai level aktivitas dari setiap kegiatan pada setiap satuan kerja atau sub bagian. Laporan barang milik Negara perlu ditingkatkan mengenai ketelitian dan kelengkapan terutama mengenai barang persediaan. Lebih ditekankan intens komunikasi baik internal maupun eksternal mengenai organisasi dan kegiatan selalu diperlukan untuk update dan segera dikomunikasikan agar informasi lebih bermanfaat dan tepat waktu. Bagian Satuan Pengawasan Intern (SPI) di PDAM Tirta Kahuripan Kabupaten Bogor perlu secara berkala rutin adanya pemantauan pencapaian sasaran mutu.

\section{DAFTAR PUSTAKA}

Association of Certified Fraud Examiners, 2016. Fraud Examiners Manual (International Edition). Texas: The Association of Certified Fraud Examiners, Inc.

Badan Pengawasan Keuangan dan Pembangunan, 2008. Fraud Auditing, Edisi kedua, BPKP, Jakarta.

Baridwan, Zaki. 2013. Intermediate Accounting, Yogyakarta: BPFE-Yogyakarta.

Cendikia, C. Syahza, A. Trisnawati, F. 2016. Pengaruh Efektifitas Pengendalian Internal dan Kesesuaian Kompensasi Terhadap Pencegahan Kecurangan 
(Fraud) Pada PDAM Tirta Siak Pekanbaru. Jurnal Online Mahasiswa-Vol. 3, No.2

Creswell, J.W. 2016.Research Design. Pendekatan Metode Kualitatif, Kuantitatif dan Metode Campuran Edisi Keempat. Yogyakarta. Penerbit Pustaka Pelajar

Fatoni, Erfin. M. dan Halim, A. 2016. Analisis Faktor-faktor Penyebab Fraud pada Badan Usaha Milik Daerah (Studi di Perusahaan Daerah Bank Perkreditan Rakyat Bank Daerah X) (Tesis). Yogyakarta. Universitas Gajah Mada.

Furqani, NS. 2016. Pengaruh Sistem Pengendalian Intern Terhadap Penerimaan Kas Pada Perusahaan Daerah Air Minum (PDAM) Kabupaten Bantaeng (Skripsi). Makassar. Universitas Negeri Makassar.

Gusnardi. 2011. Pengaruh Peran Pengendalian Internal, Audit Internal, KomiteAudit, dan Pelaksanaan Good Corporate Governance terhadap Pencegahan Fraud. Jurnal Ekuitas Vol 15, No. 1.

Herman, L.A. 2013. Pengaruh Keadilan Organisasi dan Sistem Pengendalian Intern Terhadap Kecurangan (Studi Empiris Pada Kantor Cabang Utama Bank Pemerintah di Kota Padang). Jurnal Akuntansi Vol. 1, No. 1.

Inayati, AM. 2018. Deteksi Fraud Pada Sektor Pemerintahan (Tesis). Yogyakarta. Universitas Islam Indonesia.

Jayanti, N.P.I.\& Rasmini, N.K. 2013 Pengaruh Pengendalian Intern, Motivasi, dan Reward Manajemen Pada Perilaku Etis Konsultan, E-Jurnal Akuntansi. Vol. 5, No. 1.

Kalendesang, Angelina Klesia , Linda Lambey dan Novi S. Budiarso, 2017. Analisis Efektivitas Sistem Pengendalian Internal Persediaan Barang Dagang Pada Supermarket Paragon Mart Tahuna, Jurnal Riset Akuntansi Going Concern 12 (2). Fakultas Ekonomi dan Bisnis Universitas Sam Ratulangi, Manado

Klitgaard, Robert. 2005. Penuntun Pemberantasan Korupsi dalam Pemerintahan Daerah.Jakarta: Alih Bahasa Masri Maris. Yayasan Obor Indonesia.

Kurniawan, A. Cetakan Pertama, Oktober 2015. Fraud di Sektor Publik dan Integritas Nasional.Yogyakarta: BPFE.

LPSK, 2011. Memahami Whistleblower. Jakarta : LPSK.

Lusi, DS. 2016. Evaluasi Sistem Pengendalian Internal Menggunakan Pendekatan COSO Studi Kasus Koperasi Warga Patra V (Tesis). Universitas Airlangga. Surabaya.

Ma'ruf,M. 2009Tsunami Finansial: Peluang Bisnis dan Investasi Indonesia dan setiap Individu. Jakarta: Penerbit Hikmah.

Moleong, Lexy J. Oktober 2015. Metodologi Penelitian Kualitatif Edisi Revisi. Bandung: Remaja Rosdakarya.

Mulyadi, 2017, Sistem Akuntansi. Universitas Gajah Mada. Jakarta: Salemba Empat.

Octaviani, Dian. 2018. Pengertian Sistem Pengendalian Intern. dosenakuntansi.com. www.academia.edu

Peraturan Daerah Kabupaten Bogor Nomor 8 tahun 2009, Pokok-Pokok Pengelolaan Keuangan Daerah, Cibinong.

Peraturan Pemerintah. PP Nomor 60 Tahun 2008, Sistem Pengendalian Intern Pemerintah.

Pertiwi, E.P. 2010. “Analisis Pengaruh Komponen Keahlian Internal Auditor Terhadap Pendeteksian dan Pencegahan Kecurangan (Fraud)di Inspektorat 
Jenderal Kemendagri”. Skripsi. Jurusan Akuntansi Fakultas Ekonomi dan Ilmu Sosial Universitas Islam Negeri Syarif Hidayatullah Jakarta.

Prasetyono, C.N. dan Kurniawan, F.A. 2013. Sistem Pengendalian Intern Dalam Pencegahan Fraud Pada SKPD Kabupaten Bangkalan. JAFFA, Vol. 01, No.1.

Priantara, D. 2013. Fraud Auditing \& Audit Investigation, Mitra Wacana Media, Jakarta.

Ramdhani, R. 2018. Pengaruh Audit Internal Dan Whistleblowing System Terhadap Pencegahan Kecurangan (Fraud). Studi Kasus Pada PT. PLN (Persero) Distribusi Jawa Barat (Skripsi). Universitas Pasundan. Bandung.

Ristiangsih, Ika. 2017. Telaah Konsep Fraud Diamond Theory Dalam Mendeteksi Perilaku Fraud Di Perguruan Tinggi. Prosiding Seminar Nasional dan Call For Paper Ekonomi dan Bisnis. Jember

Santoso, 2011. Efisiensi dan Efektivitas Pengelolaan Keuangan Daerah di Kabupaten Ngawi. Tesis. Surakarta : FE-Universitas Sebelas Maret.

Sayyid. A, 2014. Pemeriksaan Fraud Dalam Akuntansi Forensik dan Audit Investigatif. Al Banjari-Vol. 13, No.2.

Sugiyono, 2015. Metode Penelitian Kuantitatif, Kualitatif dan R\&D. Cetakan ke-22. Bandung: Alfabeta.

Sihombing, 2014. Analisis Fraud Diamond Dalam Mendeteksi Financial Statement Fraud : Studi Empiris pada Perusahaan Manufaktur yang terdaftar di Bursa Efek Indonesia (BEI) Tahun 2010-2012. Diponegoro Journal of Accounting Vol.03, No.2.

Sonjaya, R. 2017. Peranan Pembelajaran PPKN Daam Meningkatkan Kedisiplinan Siswa di SMPN 26 Bandung (Penelitian Analitis Deskriptif Kualitatif dalam Meningkatkan Kedisplinan Siswa di SMPN 26 Bandung) (Skripsi). Bandung : Universitas Pasundan.

Suroso, 2011.Pencegahan dan Pendeteksian Fraud Dalam Perusahaan oleh Internal Auditor.Jurnal Akuntansi Bisnis dan Publik Program Studi Akuntansi FE UNPAB Medan Vol.2 No.1.

Syafrudin, Y. 2013. Pelaksanaan Sistem Pengendalian Internal Untuk Mewujudkan Pengelolaan Keuangan Daerah Yang Efektif, Efisien, dan Bebas Korupsi. Jurnal Mahasiswa S2 Untan - Vol.3, No. 5.

Theodore, J. 2015. Pengaruh Pengendalian Internal dan Good Corporate Governance terhadap Audit Fee (KAP di Bandung) (Tesis). Bandung: Universitas Kristen Maranatha.

Undang-Undang Nomor 31 Tahun 1999 tentang Pemberantasan Tindak Pidana Korupsi.

Wahyudin, A. dan Cahyaningdyah, D. dan Baroroh, N. 2014. Penguatan Sistem Pengendalian Intern Sebagai Upaya Meminimalisir Praktek Tidak Sehat Dalam Tata Kelola Keuangan Koperasi. Jurnal Penerapan Teknologi dan Pembelajaran-Vol.12, No.2.

Wardhani, I.I. 2018. Faktor-faktor yang Mempengaruhi Pencegahan Fraud Pengadaan Barang dan Jasa di Uniy Layanan Pengadaan (ULP) Provinsi Sumatra Utara Berbasis E-procurement. (Tesis). Yogyakarta: Universitas Islam Indonesia

Widjaja, Amin. 2012. Forensic \& Investigative Accounting: Pendekatan Kasus, Jakarta: Harvarindo. 